\title{
Limb dominance for fifth metatarsal fracture in football players is position-specific
}

\author{
Tomoya Ueda ${ }^{12^{*}}$, Hiroaki Hobara', Yoshiyuki Kobayashi ${ }^{1}$, Masaaki Mochimaru' ${ }^{1}$, Hiroshi Mizoguchi ${ }^{2}$ \\ From 4th Congress of the International Foot and Ankle Biomechanics (i-FAB) Community \\ Busan, Korea. 8-11 April 2014
}

Fifth metatarsal fractures (5MtF) are one of the most common traumatic foot injuries in football player [1,2]. A previous study demonstrated that the $5 \mathrm{MtF}$ in football players occur frequently in their non-dominant limb [2]. Since different playing positions requires different physical demands in match-play [3], the aim of this study was to examine the hypothesis that the limb dominance for $5 \mathrm{MtF}$ is position-specific. Using a publicly-available injured reserve list in Japan professional football league (J-League) during 2008-2013 seasons, we collected a total of 82 cases of 5MtF. Positions (forward players: FW, midfielders: MF, and defenders: DF) and limb dominance in each player was also identified by officially-released profile in their team. To test whether the percentage of limb dominance of $5 \mathrm{MtF}$ differed from chance, we used a binomial test to compare reported incidence of $5 \mathrm{MtF}$ in non-dominant limb out of all cases to the theoretical probability of $50 \%$. In the present study, 24 (29.3\%), $33(40.2 \%)$ and $25(30.5 \%)$ cases of 82 cases were classified into FW, MF and DF, respectively (Figure 1-A). There were no significant differences in the incidence of $5 \mathrm{MtF}$ among three groups ( $p=0.41$, Chi-square test). Overall, the $5 \mathrm{MtF}$ tended to be occurred in non-dominant limb (Figure 1-B; $p<0.01$ ). However, as shown in Figure 1-B, the trend was more pronounced in DF $(p<0.01)$, and not in FW $(p=0.15)$ and MF $(p=0.24)$. These results suggest that limb dominance for $5 \mathrm{MtF}$ is position-specific in football players.

\section{Authors' details}

${ }^{1}$ National Institute of Advanced Industrial Science and Technology, Tokyo, 135-0064, Japan. ${ }^{2}$ Tokyo University of Science, Chiba, 278-8510, Japan.

Published: 8 April 2014

\section{References}

1. Ekstrand J, van Dijk CN: Fifth metatarsal fractures among male professional footballers: a potential career-ending disease. $\mathrm{Br} J$ Sports Med 2013, 47:754-758.

2. Ekstrand J, Torstveit MK: Stress fractures in elite male football players. Scand J Med Sci Sports 2012, 22:341-346.
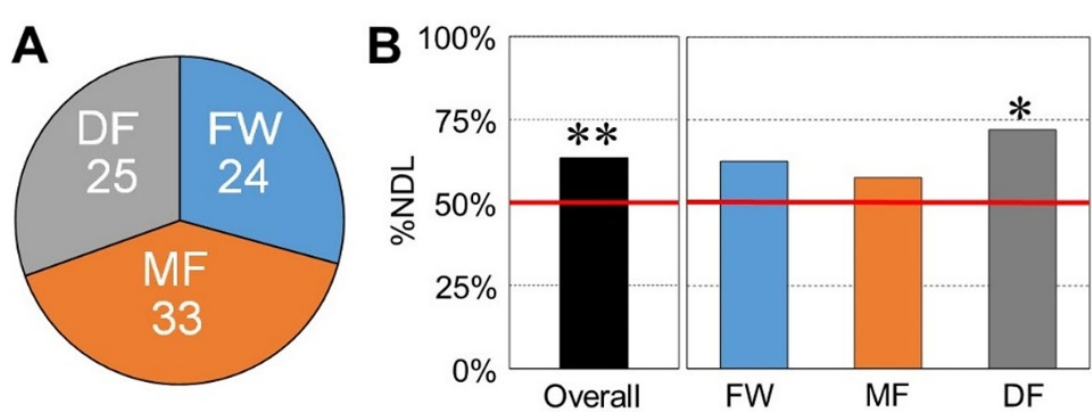

Figure $1 \mathrm{~A}$ : Incidence of fifth metatarsal fracture in three groups. B: Percentage of non-dominant limb (\%NDL) for fifth metatarsal fracture in each group.

'National Institute of Advanced Industrial Science and Technology, Tokyo,

135-0064, Japan

Full list of author information is available at the end of the article 
3. Bloomfield J, Polman R, O'Donoghue P: Physical demands of different positions in FA Premier League soccer. J Sports Sci Med 2007, 6:63-70.

doi:10.1186/1757-1146-7-S1-A86

Cite this article as: Ueda et al.: Limb dominance for fifth metatarsal

fracture in football players is position-specific. Journal of Foot and Ankle

Research 2014 7(Suppl 1):A86.

Submit your next manuscript to BioMed Central and take full advantage of:

- Convenient online submission

- Thorough peer review

- No space constraints or color figure charges

- Immediate publication on acceptance

- Inclusion in PubMed, CAS, Scopus and Google Scholar

- Research which is freely available for redistribution

Submit your manuscript at 